УДК 37.091.12:510.2]:008 - 047.22

DOI: 10.37026/2520-6427-2020-103-3-62-65
Олена МАРЧЕНКО,

кандидат педагогічних наук, дочент кафедри природничо-математичної освіти Рівненського ОІППО

\title{
РЕАЛІЗАЦІЯ ОТЕАМ-ПІДХОДУ ДО ФОРМУВАННЯ КРЕАТИВНОЇ КОМПЕТЕНЦІї ЗДОБУВАЧІВ ОСВІТИ У ПРОЦЕСІ ВИВЧЕННЯ МАТЕМАТИКИ
}

У статті окреслені методологічні аспекти реалізації STEAM-кониепиї як сучасного дидактичного принципу інтеграції математичних і мистецько-культурологічних знань у прочесі здобуття природничо-математичної освіти з метою формування й розвитку креативної компетенції учасників освітнього процесу. На основі аналізу вітчизняних нормативно-правових документів $i$ зарубіжних наукових публікачій досліджено роль $і$ значення включення STEAM-niдходу у проиес реалізаиї Кониепиії розвитку STEM-орієнтованоі природничо-математичної освіти в Україні.

Ключові слова: STEM-освіта, STEAM-nidxid, трансдисииплінарний підхід до здобуття природничо-математичної освіти, мистецько-культурологічні й креативні компетенції здобувачів природничо-математичної освіти.

В статье очерчены методологические аспекты реализачии STEAM-кониепиии как современного дидактического принципа интеграции математических и художественно-культурологических знаний в прочессе получения естественно-математического образования с иелью формирования и развития креативной компетенции участников образовательного прочесса. На основе анализа отечественных нормативно-правовых документов и зарубежных научных публикаций исследовано роль и значение включения STEAM-подхода в прочесс реализачии Концепции развития STEM-ориентированного естественно-математического образования в Украине.

Ключевые слова: STEM-образование, STEAM-подход, трансдисциплинарный подход $\kappa$ получению естественно-математического образования, художественно-культурологические и креативные компетениии соискателей естественно-математического образования.

According to the Concept of development mathematics and technology-focused education in Ukraine the application of the STEM-approach is a perspective direction. Inclusion in this direction the STEAM-approach is the basis of incorporation science, technology, design and art into the holistically oriented mathematics curriculum. STEAM-approach promotes the implementation of the interdisciplinary process of teaching and learning mathematics.
The term «STEAM-approach» means the learning process that uses science-oriented and design projects based on the knowledges of mathematics and arts as an access point guiding student's creativity, cultural competence and emotional intelligence.

Considering that STEM-education is recognized as a perspective mode to preparing 21 st century economy workers, who are capable not only to apply mathematics in their professional career, but reveal essential skills such as ability to innovation, problem-solving, collaboration in multicultural projects, communication based on widely developed emotional intelligence, the STEAM-approach helps students and teachers to achieve these goals by diversing learning and teaching opportunities.

In keeping with the Year of Mathematical Education 2020/2021 in Ukraine the regional scientific and methodological project «The Cultural Codes of Mathematics» is aimed on integrating aesthetic elements into the teaching of mathematics for realization of STEM/STEAM-approach to education. This project should make some contribution to the increasing the potential for successful learning of mathematics in all types of learners, especially gifted in arts. Inquiry, collaboration and an emphasis, expressed by the participants of this project, will contribute to the formation of teacher's and student's awareness of the interconnection of mathematics and culture on the examples of architecture, painting, design and other manifestations of culture.

Key words: STEM-education, STEAM-approach, transdisciplinary approach to mathematics and technology-focused education, artistic, cultural and creative competencies of applicants of mathematics and technology-focused education.

Постановка проблеми. Перспективним напрямом розвитку освіти в Україні, чітко окресленим у Концепції реалізації державної політики у галузі реформування загальної середньої освіти на період до 2029 року «Нова українська школа», $є$ природничо-математична освіта, яка грунтується на застосуванні STEM-підходу. Розпорядження Кабінету Miністрів України «Про схвалення Концепції розвитку природничо-математичної освіти (STEM-освіти)» визначає методологію наукового розуміння сутності STEM-освіти як важливого елемента «фундаменту 
конкурентоздатності та економічного зростання нашої держави, що покликані формувати новітні STEMкомпетентності громадян» [2].

Концепція розвитку STEM-освіти (далі-Кониепція) визначає іiї як трансдисциплінарний підхід, який передбачає практичне застосування знань, зокрема 3 математики, для розуміння провідних трендів розвитку глобалізованого світу, надання STEM-орієнтованих освітніх послуг, важливою складовою яких $\epsilon$ формування як освітніх, так і життєвих компетентностей. Таке розуміння STEM-освіти визначає необхідність всебічного грунтовного аналізу методології впровадження міждисциплінарного підходу шляхом розширення STEM-освіти завдяки включенню в неї мистецьких, творчих дисциплін у контексті реалізації STЕАМ-підходу (STEM and Arts) [2].

Аналіз наукових досліджень і публікацій. Концепція визначає термін STEM як акронім від англійських слів science - природничі науки, technology - технології, engineering - інженерія, проєктування, дизайн, mathematics - математика, роз'яснює дидактичну категорію STEM-компетентність як здатність особистості застосовувати знання та вміння, здобуті у процесі вивчення STEM-предметів у своєму повсякденному житті. У цьому розумінні Концепція повністю відповідає сучасному баченню освітнього процесу як спільної діяльності педагогів і здобувачів освіти, побудованої на дидактичних засадах формування й розвитку як розумово-пізнавальних, соціально-культурологічних, так і креативних якостей молоді.

Представники міжнародної науково-педагогічної спільноти, зокрема Сьюзен Райлі (Susan Riley) [7], Жоржет Якмен (Georgette Yakman) [8] та інші, подають ще одне трактування STEAM-підходу, яке особливо підкреслює важливість практичного впровадження міждисциплінарного напряму, а саме розуміння появи літери А у цьому терміні як першої в англійському слові all - усі. Це означає, що актуальним напрямом STEAM-підходу, зокрема у навчанні математики, є ознайомлення здобувачів освіти із прикладами використання математичних знань художниками, архітекторами, скульпторами, композиторами, поетами, дизайнерами, інженерами для створення всесвітньо відомих шедеврів художнього, музичного, літературного і прикладного мистецтва, які протягом тисячоліть визначають найвищі досягнення культури всього людства.

Так, наприклад, Сьюзен Райлі, засновниця The Institute for Arts Integration and STEAM (Інститут об'єднання мистецтв і STEAM, штат Меріленд, США), визначає STEAM-концепцію як дидактичний принцип поєднання сучасної природничо-математичної освіти 3 мистецькими дисциплінами. У цьому розуміннні STEAM-орієнтована математична освіта може, на думку Сьюзен Райлі, стати «точкою доступу» здобувачів освіти до успішного формування впродовж вивчення природничо-математичних дисциплін таких важливих складових множинного інтелекту як художній та емоційний інтелект, креативність, критичне мислення, стійка потреба самостійного здобуття нових знань, здатність знаходити зв'язки всередині та ззовні системи знань тощо. Професорка Жоржет Якмен, міжнародний експерт у галузі впровадження STEAM-освіти, зазначає, що центральним сенсом філософії STEAM-концепції є фасилітація розуміння фундаментальної науки (наприклад, математики) на основі мультидисциплінарного підходу, який поєднує опанування програмового матеріалу із дослідженням його прикладних застосувань, зокрема й у мистецтві. Важливо, що, на думку Ж. Якмен, STEAM-орієнтована методика навчання базується на застосуванні проєктного навчання, проблемно орієнтованого вивчення природничо-математичних предметів, самостійного створення здобувачами освіти власних, нових для себе, освітніх цінностей, практик співпраці й взаємодії (зокрема й мережевої) у контексті навчальних дослідницьких й мистецьких розробок, які ілюструють втілення наукової інформації у процес створення артоб'єктів.

Мета статті - проаналізувати, як STEAM-підхід уможливлює для здобувачів освіти, обдарованих у гуманітарно-мистецькій галузі, вихід за межі традиційного вивчення математики завдяки подоланню розриву між обов'язковим рівнем предметних знань i компетентностей та наявними унікальними індивідуальними інтересами, нахилами, здібностями кожної дитини i, зрештою, дозволяє усвідомити своє власне справжнє покликання, можливий напрям майбутньої професійної діяльності.

Виклад основного матеріалу. Практики зарубіжної шкільної, а подекуди й університетської освіти свідчать про те, що STEM-підхід набуває свого подальшого розвитку й поширення у вигляді STEAM-освіти, яка здатна поєднати знання й розуміння важливості інформації щодо видатних здобутків науки й мистецтва, які визначають собою найвищі досягнення людства. У міжнародних професійних педагогічних спільнотах, як зокрема «All Education School» [9] («Bce про шкільну освіту») йдеться, зокрема, про те, що STEAM-підхід дозволяє, на відміну від традиційного навчання, на практиці реалізовувати принцип дитиноцентризму, який $є$ основою Концепції Нової української школи, особливо у процесі опанування здобувачами освіти 3 різними напрямами індивідуальних здібностей і обдарувань шкільної програми 3 математики. Так, наприклад, STEAM-учитель математики може пропонувати своїм учням співпрацю у межах навчальних проєктів, спрямованих на дослідження проявів знань, закономірностей і методів математики у мистецтві, архітектурі, інженерії, дизайні тощо. Таким є один із шляхів формування у молоді навичок XXI століття, серед яких варто особливо відзначити когнітивну гнучкість, адаптивність при визначенні індивідуальної освітньої траєкторії, полікультурну компетентність, яка $є$ необхідною складовою продуктивного життя у глобалізованому світі.

На досягнення таких амбітних цілей спрямовано науково-методичний проєкт «Культурні коди математики», затверджений наказом управління освіти і науки Рівненської обласної державної адміністрації, презентація й функціонування якого $є$ складовою комплексу заходів щодо проведення у 2020/2021 навчальному році Року математичної освіти в Україні, затвердженого Указом Президента України №31/2020 [3] (далі - Указ). Відповідно до перспективних завдань, окреслених в Указі, проєкт «Культурні коди математики» спрямовано на впровадження у навчання математики сучасних практико орієнтованих засад, підвищення якості навчально-методичного забезпечення вивчення математики та формування однієї з актуальних складових внеску математики у формування ключових освітніх компетентностей обізнаності та самовираження у галузі культури й формування та розвитку полікультурної компетентності всіх учасників освітнього процесу. Зазначені цілі проєкту повністю відповідають передбаченій в 
Указі необхідності модернізації методології шкільної математичної освіти на основі урахування кращих вітчизняних та міжнародних практик, вивчення та впровадження досвіду держав, які демонструють високі показники з математичної компетентності. На основі аналізу результатів міжнародного дослідження якості освіти PISA [10] можна зробити висновок, що такими державами $\epsilon$ ті, що практикують упровадження STEM/STEAM-підходу до навчання математики, який, зокрема, забезпечує усвідомлення здобувачами освіти взаємозв'язку математики та культури на прикладах із дослідження математичних моделей і закономірностей у різних видах мистецтва - архітектурі, живописі, дизайні тощо, розуміння ними важливості внеску математики у загальносвітову культуру.

Проєкт «Культурні коди математики» відповідає сучасній методології й практикам навчання математики, теоретичні основи яких обговорюються ученими-дидактами, методистами, вчителями країн, де застосовується STEM/STEAM-підхід, наприклад, на pecypci «Fresh Ideas for Teaching» [6], автори дописів якого підкреслюють необхідність розширення сучасної методики навчання математики засобами STEAM-освіти. У статті «Expanding the Math Classroom with STEM or STEAM», розміщеній на цьому pecypci, iï авторка Deborah McGinley (Дебора МакГінлі), вчитель-експерт із навчання математики (м. Орландо, штат Флорида, США), зазначає важливість доповнення STEM-напряму інтеграцією до нього артпідходу і наводить приклади такої інтеграції, які відповідають ідеології проєкту «Культурні коди математики» та його основним цілям і завданням:

- розвиток полікультурної компетентності педагогів і здобувачів освіти на основі застосування STEAM-підходу до навчання й вивчення математики»;

- практична реалізація базових положень концептуальної моделі освітніх компетентностей, на реалізацію яких спрямована Концепція розвитку природничо-математичної освіти (STEM-освіти) в Україні;

- формування обізнаності у галузі культури також і у процесі навчання й вивчення математики, особливо для саморозвитку тих здобувачів освіти, для яких традиційні методи навчання математики є неефективними, що дозволить їм усвідомлено й умотивовано будувати індивідуальну освітню траєкторію;

- усвідомлення всіма учасниками освітнього процесу взаємозв'язків математики та культури на прикладах 3 архітектури, живопису, дизайну, інженерії тощо на основі практичного втілення дослідницького, проєктного підходу до навчання й вивчення математики, а також активного застосування інноваційних практичних методик, зокрема «мейкерства» (3 допомогою, наприклад, 3D-технологій) для створення власних розробок, у яких математичні знання стануть основою розуміння естетики й візуальної гармонії мистецького твору, створеного власноруч.

Проєкт «Культурні коди математики» спрямований на вирішення важливих завдань, окреслених Концепцією розвитку природничо-математичної освіти (STEM-освіти) в Україні, а саме на всебічний розвиток особистості шляхом виявлення іiі індивідуальних природних нахилів і здібностей, а також формування освіченої в сучасному розумінні людини, яка має стійку мотивацію до розвитку впродовж життя здобутих у процесі навчання в закладі освіти компетентностей щодо практичного і творчого застосування математичних знань.
Так, працюючи у пошуково-дослідницькому напрямі проєкту «Симетрія в математиці та архітектуpi», його учасники матимуть змогу у практичному й мистецько-прикладному вимірі дослідити використання симетрії як властивості об'єкта відтворювати себе при певних змінах чи перетвореннях, наприклад, у проєктуванні й будівництві всесвітньо відомих пам'яток культури, а саме, мавзолею Тадж Махал (Індія), збудованого у XVII столітті, чи архітектурного ансамблю Альгамбра (Іспанія), будівництво якого тривало протягом XIII-XIV століть тощо; беручи участь у напрямі «Пропорція в математиці й мистецтві», учасники проєкту вчитимуться розуміти значення пропорції як математичного підгрунтя архітектурної гармонії й засобу для створення збалансованої рівноваги між цілим і частинами таких шедеврів образотворчого мистецтва як, зокрема, картини знаменитих художників Відродження - Леонардо да Вінчі, Боттічеллі та багатьох інших, а також геніїв мистецтва XX століття, наприклад, всесвітньо відомого архітектора Ле Корбюз'є тощо.

Різноманіття напрямів проєкту дозволить його учасникам не лише усвідомити практичну значущість законів і методів математики для створення мистецьких об'єктів, які належать до світової культурної спадщини усього людства, але й розвинути полікультурну компетентність і креативні компетенції як учителів математики, так і здобувачів освіти. Так, наприклад, працюючи за напрямом «Парабола в архітектурі», учасники проєкту не лише матимуть змогу дослідити використання параболи у таких знаменитих спорудах як Тріумфальна арка в Парижі чи палац Гуеля в Барселоні, побудованого за проєктом знаменитого архітектора Антоніо Гауді, але й здійснити віртуальну прогулянку цими містами за допомогою мережевого проєкту Google Arts \& Culture, що дозволить значно розширити уявлення про культурні особливості організації суспільного простору в цих мегаполісах, формувати мотивацію до подальшого розвитку когнітивних навичок освіченої людини, а саме: пошуку, співставлення, упорядкування та відбору валідних даних для задоволення потреб культурної самоідентифікації та особистісного саморозвитку, створення, розуміння, інтерпретації, аналізу та екстраполяції емпіричних даних, перевірки їх достовірності, надійності тощо. Про важливість системної освітньої діяльності 3 поглиблення й розширення вказаних компетенцій йдеться у Концепції розвитку природничо-математичної освіти (STEM-освіти) [2].

Висновки. Таким чином, викладена вище аргументація дозволяє стверджувати, що доповнення STEM-напряму розвитку вітчизняної освіти ідеями й методами STEAM-підходу до навчання й вивчення математики відповідає як вимогам додержання державних гарантій із реалізації права на якісну освіту для ii здобувачів із різними ступенями навчальних досягнень та індивідуальними нахилами й обдаруваннями, так і збагачення практичної методики навчання математики засобами формування й розвитку тих життєвих компетентностей, які забезпечать випускникам Нової української школи здатність до розуміння культурних цінностей і надбань людства, зв'язків фундаментальної науки з різноманітними галузями життя в сучасному глобалізованому полікультурному світі і як наслідок - успішної продуктивної адаптації в ньому й мотивації до подальшого саморозвитку завдяки усвідомленню переваг умотивованої й безперервної освітньої діяльності. 
Подальші дослідження із даної проблематики плануємо спрямовувати на системний аналіз концептуальних ідей, сутності та складових методики реалізації STEAM-підходу до навчання й вивчення математики з метою розвитку креативної компетенції здобувачів освіти та полікультурної компетентності вчителів математики. Важливим подальшим напрямом $є$ також дослідження впливу STEAM-підходу на підвищення рівня професійної компетентності учителів математики, реалізацію їхніх потреб щодо саморозвитку з метою покращення конкурентоздатності в умовах багатокультурного глобалізованого світу.

\section{СПИСОК ВИКОРИСТАНОЇ ЛІТЕРАТУРИ}

1. Концепція STEM-освіти в Україні : проєкт URL: http://mk-kor.at.ua/STEM/STEM_2017.pdf (дата звернення: 21.07.2020).

2. Про схвалення Концепції розвитку природничо-математичної освіти (STEM-освіти) : розпорядження Кабінету Міністрів України від 5 серпня 2020 p. №960-p. URL: https://zakon.rada.gov.ua/ laws/show/960-2020-\%D1\%80\#Text (дата звернення: 14.09.2020).

3. Про оголошення 2020/2021 навчального року Роком математичної освіти в Україні : Указ Президента України №31/2020. URL: https://www.president. gov.ua/documents/312020-32165 (дата звернення: 24.07.2020).

УДК 37.018.43:378

DOI: 10.37026/2520-6427-2020-103-3-66-65
4. What is STEAM Education? URL: https:// educationcloset.com/what-is-steam-education-in-k-12schools/ (дата звернення: 22.07.2020).

5. How STEAM education develops 21st century skills. URL: https://www.studyinternational.com/news/ steam-education/ (дата звернення: 22.07.2020).

6. Expanding the Math Classroom with STEM or STEAM. URL: https://blog.savvas.com/expanding-themath-classroom-with-stem-or-steam/ (дата звернення: 25.07.2020).

7. Susan Riley. Особиста сторінка Сьюзен Райлі в міжнародній професійній спільноті Linkedin. URL: https://www.linkedin.com/in/susan-riley-78199140. (дата звернення: 23.07.2020).

8. Georgette Yakman. Developing STEAM Education to Improve Student's Innovative Ability. URL: https://steamedu.com/developing-steam-education-toimprove-students-innovative-ability/ (дата звернення: 23.07.2020)

9. All Education School. Міжнародна мережева педагогічна спільнота. URL: https://www. alleducationschools.com/resources/steam-education/ (дата звернення: 24.07.2020).

10. PISA 2018 Results.Combined Executive Summaries. URL: https://www.oecd.org/pisa/Combined Executive_Summaries_PISA_2018.pdf (дата звернення: 14.09.2020).

Дата надходження до редакиї: 14.09.2020 p.

Наталія РИСИНЕЦЬ,

завідувач економіко-правового відділення

Коледжу економіки і права

Вінницького кооперативного інституту, м. Вінниця

\section{ЗАСТОСУВАННЯ ІННОВАЦІЙНИХ ТЕХНОЛОГІЙ 3 МЕТОЮ ФОРМУВАННЯ ГОТОВНОСТІ ФАХІВЦІВ ІЗ МІЖНАРОДНОГО ПРАВА ДО ПРОФЕСІЙНОЇ ДІЯЛЬНОСТІ}

\footnotetext{
У статті означено та проаналізовано проблему застосування інновачійних технологій, зокрема технологій презентаиій, з метою формування готовності фахівиів із міжнародного права до професійної діяльності. Розкрито методичні аспекти використання сучасних технологій презентацій під час навчання фахівиів із міжнародного права: изілі та головні елементи, вибір формату, конструювання тем, організаційна підготовка, очінювання результатів та інше. Основну увагу приділено висвітленню особливостей
}

використання скрайбінгу та мнемоніки на лекційних заняттях, впливу технологій презентаиій на мотивацію, зацікавленість студентів та якісну успішність. Аналіз педагогічної та правової літератури, а також власний педагогічний досвід свідчать, щзо проблема впровадження технологій презентацій в освітній прочес повністю не вивчена та потребує подальших досліджень. Особливо гостро ияе відчувається в умовах переходу системи освіти на дистаниійне навчання, зокрема у зв'язку з пандемією коронавірусу. 